\title{
Civil Law Consequences of Corruption and Bribery in France
}

\author{
Beatrice Jaluzot/Michaela Meiselles*
}

\section{A. Introduction}

A range of colourful expressions is used to describe corruption in the French language, including such expressions as "wine pots" (pots-de-vin) or "under the table" (dessous de table), which both give a hint as to the depth and age of this phenomenon. In everyday parlance, corruption is defined as the use of reprehensible means to induce somebody to act against their duty or conscience. ${ }^{1}$ This definition is relatively wide and reveals that corruption is a protean phenomenon. Since corruption is constantly evolving, it requires a protean set of legal measures to fight efficiently against it. Corruption is usually aimed at personal gain, the attainment of business interests, public contracts or a favourable decision and consists of an illicit payment followed by an attempt to clean-up the funds and ultimately, by the granting of a favourable decision. ${ }^{2}$ Reality shows that corruption is versatile and always assumes new forms to avoid falling under the law.

As a result, French law adopts a systematically unbiased approach, combating the most striking examples of corruption. Up until now, this fight has evolved in three main stages: the fight against domestic corruption of public officials; the fight against domestic corruption within the private sector; and more recently, the fight against transnational bribery.

The fight against domestic corruption of public officials dates back to the era of the French Revolution, with the introduction of the first Penal Code (Code pénal, CP) in 1791. This Code stated that "corruption de fonctionnaires" should be severely punished through the repudiation of civil rights ("dégradation civique") and more severely, where the official was a judge, a jury member or a police officer, by 20 years imprisonment and even execution, where the official was a member of the legislature. ${ }^{3}$ From this point onwards, the French legal system has continuously imposed sanctions in relation to this kind of corruption. An important part of the legal framework dealing with domestic cor-

* Beatrice Jaluzot is Maître de conférences en droit privé and directrice-adjointe de l'Institut de Droit Comparé Edouard Lambert (Université Jean Moulin-Lyon 3); Michaela Meiselles is Academic Director, LLM International and European Law, and Lecturer (Law, Ethics and Negotiation) (Law School, Université Jean Moulin-Lyon 3).

1 Le Petit Robert, dictionnaire de la langue française: "Corruption: Emploi de moyens condamnables pour faire agir quelqu'un contre son devoir, sa conscience."

2 Hunault, Rapport au nom de la commission des lois de l'Assemblée Nationale sur le projet de loi (no. 171) relatif à la lutte contre la corruption, 3 October 2007, 7, available at $<$ http://www.assembleenationale.fr/13/rapports/r0243.asp>.

3 Jeandidier, Du délit de corruption et des défauts qui l'affectent, La Semaine Juridique (JCP) 2002 I 166 , no. 3. 
ruption by public officials emerged from this period, namely the offence of "concussion" (Art. 432-10 CP).

The fight against domestic corruption within the private sector emerged between the 1980s and 1990s, using a different approach, such as transparency in company, accounting and public procurement law. French law targets the aims as well as the mechanisms of corruption; it combats corruption directly as well as indirectly. For instance, corporate governance aims to achieve increased transparency thus exposing undue payments to a greater extent than previously, in corporate accounting; unfair competition law aims to fight against illicit agreements which are concluded through the payment of bribes. One of the most prominent developments in this area is the recent reform of the law on public procurement. Corruption is now associated with numerous and various financial infringements, such as the use of corporate property in bad faith ("abus de bien sociaux", Art. L. 241-3, $4^{\circ}$ Code de commerce (C.com.); L. 242-6, $3^{\circ}$ C.com., money laundering ("blanchiment de capitaux", Art. 324-1 CP) and the offence of favouritism ("délit de favoritisme", Art. 432-14 CP). ${ }^{4}$ The willingness of the judiciary to use rules (for instance the use in bad faith of company's property, Art. L. 241-3, $4^{\circ}$ and L. 242-6, $3^{\circ}$ C.com.) as sanctions in situations not otherwise intended to be covered by these rules, has also improved the situation.

A law officially related to "preventing corruption and transparency in the economic life and public procedures" 5 was enacted on 29 January 1993. One of the most interesting and important features of this law is the creation of a "central service charged with the responsibility of preventing corruption" (known as the Service central de prévention de la corruption, SCPC). Amongst its tasks is the discovery of new mechanisms employed in the commission of corruption and then the communication of information to its various partners about these said mechanisms, in a bid to ensure a corruption-free environment within public and private establishments. Supervised by the Ministry of Justice, this service is responsible for collecting information, aimed at helping to detect and prevent corruption. The SCPC has a duty to report its activities annually to both the Prime Minister and the Minister of Justice.

Up until the end of the 20th century, transnational bribery had been endorsed by French law. French corporations that had incurred business-related costs were entitled to tax exemptions, where the payment had been authorised by the Finance Ministry. Payments to foreign public officials, with the consent of the Conseil d'Etat, had been accorded preferential tax treatment as these payments were considered to be in the interests of the corporation. ${ }^{6}$ Such favourable treatment was discontinued with the entry into force of the Finance Act of 1997 (loi de finances rectificative pour 1997), ${ }^{7}$ which brought French law in line with the OECD Convention on Combating Bribery of For-

4 This Article concerns infringements against free access to public procurement and rupture of equality of tenders ("atteinte à la liberté d'accès et à l'égalité des candidats dans l'accès aux marches publics"). Laws and court decisions are available on the website legifrance (service public de la diffusion du droit) $<$ http://www.legifrance.gouv.fr $>$.

5 Loi no. 93-122 "relative à la prevention de la corruption et à la transparence de la vie économique et des procédures publiques".

6 Conseil d'Etat, 13 July 1983, no. 33942.

7 Loi de finances rectificative pour 1997, no. 97-1239 of 29 December 1997. 
eign Public Officials in International Business Transactions and introduced Art. 39(2) bis into the Code général des Impôts (CGI). ${ }^{8}$

This Convention, ratified in 1998, is part of a series of international conventions which aim to combat transnational bribery and which involve France as a State party. Accordingly, French criminal law also gave effect to the EU Convention relating to Corruption of European Officials, ${ }^{9}$ through the introduction of the Act of 30 June 2000, relating to "the fight against corruption". 10

The anti-corruption instruments of the European Council, namely the Criminal Law Convention and the Civil Law Convention, were also ratified by the French Parliament in $2005^{11}$ and enacted in November 2007. ${ }^{12}$ This Act of 11 November 2007 also aimed to harmonise the stance of the $\mathrm{CP}$ on corruption.

However, one of the aims of the legislator was to enact the Civil Law Convention against corruption, issued by the European Council. During the debate, reports on the proposal confirmed that French civil law would largely conform to the requirements of the Convention; ${ }^{13}$ except in certain areas of the law, such as labour law, which required more substantial reforms, in order to protect whistleblowers. Consequently no special civil law rules on corruption were enacted.

How does French civil law address corruption? It does not address per se, as the civil law remedy depends on the decision arrived at under criminal law. Pursuant to Art. 2 Code de Procédure Pénale (Criminal Procedure Code, CCP), a victim can obtain civil

8 Art. 39(2) bis CGI: "A compter de l'entrée en vigueur sur le territoire de la République de la convention sur la lutte contre la corruption d'agents publics étrangers dans les transactions commerciales internationales, les sommes versées ou les avantages octroyés, directement ou par des intermédiaires, au profit d'un agent public au sens du 4 de l'article 1er de ladite convention ou d'un tiers pour que cet agent agisse ou s'abstienne d'agir dans l'exécution de fonctions officielles, en vue d'obtenir ou conserver un marché ou un autre avantage indu dans des transactions commerciales internationales, ne sont pas admis en déduction des bénéfices soumis à l'impôt."

("Since the coming into force of the Convention on Combating Bribery of Foreign Public Officials in International Business Transactions in the territory of the Republic of France, the sums discharged or the advantages granted, directly or by an intermediary, for the benefit of a public agent in the sense of Art. 4(1) of this Convention, or of a third party with the aim of influencing the agent to act or not to act within the legally permitted scope when exercising his official duties, in order to obtain or sustain a competitive or another unjustified advantage within the international commercial transactions, do not count as deductible expenses for purposes of tax deductibility.").

9 Council Act of 26 May 1997 drawing up the Convention made on the basis of Art. K.3(2)(c) of the Treaty on European Union, on the fight against corruption involving officials of the European Communities or officials of Member States of the European Union (O.J. C 195 of 25 June 1997).

10 Loi no. 2000-595, modifying the Criminal Code and the Code on Criminal Procedure regarding the fight against corruption (modifiant le code pénal et le code de procédure pénale relative à la lutte contre la corruption).

11 Loi no. 2005-103 of 11 February 2005 authorising the ratification of the Civil Law Convention on Corruption (autorisant la ratification de la convention civile sur la corruption); Loi no. 2005-104 of 11 February 2005 authorising the ratification of the Criminal Law Convention on Corruption (autorisant la ratification de la convention pénale sur la corruption).

12 Loi no. 2007-1598 of 13 November 2007 on the fight against corruption (relative à la lutte contre la corruption).

13 Hunault, Rapport 16; Portelli, Rapport au Sénat no. 51 (2007-2008), fait au nom de la commission des lois, 24 October 2007, 29, available at <http://www.senat.fr/rap/107-051/107-051.html $>$. 
compensation from a Criminal law court under certain conditions. This is called the "action publique" which is subordinate to the criminal law decision: once a criminal offence is acknowledged (B), civil damages are awarded (C).

\section{B. Legal Qualification and Criminal Law Treatment}

Accordingly, for one to understand the civil law treatment of corruption, it is imperative firstly, to address the criminal law treatment of corruption.

As for rules which directly address corruption, French criminal law appears to be patchy although the recent 2007 Act has attempted to adopt a more uniform approach to infringements as well as sanctions. There are still different kinds of criminal law offences and different kinds of persons involved (I); rules of sanctions are narrowly defined (II); this treatment does not really correspond with reality, as case law demonstrates (III).

\section{Criminal Law Offences}

French criminal law offers different kinds of infringements directly related to corruption and considers a wide range of categories of persons and situations. Corruption may consist of active or passive corruption, as well as active or passive trafficking in influence. These infringements may be related to public officials, offences committed against public administration pursued by private persons, EU or foreign public officials, judicial officials, or, more recently, to a "person without any public responsibility".

Active corruption is corruption considered from the briber's point of view, that is the person who grants the undue advantage. Art. 433-1 CP defines active corruption as follows:

"Unlawfully proffering, at any time, directly or indirectly, any offer, promise, donation, gift or reward, in order to induce a person ... (1) to carry out or abstain from carrying out an act pertaining to his office, duty, or mandate, or facilitated by his office, duty or mandate (2) or to abuse his real or alleged influence with a view to obtaining distinctions, employment, contracts or any other favourable decision."

It could be an offence committed by a private person against the administration (Art. 433-1 CP), or an offence against the European Administration (Art. 435-3 CP), it could involve judicial persons (Art. 435-9 CP) or a person without any public responsibility (Art. 445-1 CP).

Passive corruption is its counterpart, that is corruption considered from the recipient's point of view. Art. 432-11 CP defines passive corruption as follows:

"the direct or indirect request or acceptance without right and at any time of offers, promises, donations, gifts or advantages." 
Such an offence could be committed by a public official (Art. 432-11 CP), an EU official (Art. 435-1 CP), a judicial official (Art. 435-7 CP), or a person "not holding any public office" (Art. 445-2 CP).

Trafficking in influence seems to be a legal term unique to French law. This offence focuses on the act of using or abusing the influence of an official. Art. 432-11, $2^{\circ} \mathrm{CP}$ requires that the public official abuses "his real or alleged influence with a view to obtaining from any public body or administrative body any preferential treatment, employment, contract or any other favourable decision." Just as corruption can be either passive or active so can trafficking in influence. Passive trafficking in influence occurs when a public official receives a bribe in order to induce him to use his influence (for instance Art. 433-2, 435-2, 435-7 CP); active trafficking in influence occurs when someone offers a public official a bribe to incite him to abuse his influence (for instance, Art. 435-4, 435-9 CP). For instance, in a case dealt with by the Criminal Chamber of the Cour de cassation in 2004, a man was convicted of trafficking in influence after offering to sell and selling various items at advantageous prices to DCN agents (Direction de la Construction Navale, experts in naval defence) and inviting the agents out on various occasions. The man had obtained contracts for supply and maintenance from these agents. ${ }^{14}$ Judges stated that it was obvious that the indicted only offered these benefits to the agents with the awareness of their real or supposed influence on the granting of service orders or trade agreements.

According to the Penal Code, these infringements only relate to specific persons. The first and oldest category involves public officials. According to Art. 432-11 CP, this infringement addresses persons holding public authority or discharging a public service mission, or persons holding a public electoral mandate. The second category involves private persons where they commit an offence against public administration (Art. 433-1 et seq. CP). The scope covered by the third category continually expands: from the outset, this category embraced the corruption of EU officials and since 2007, its scope has widened to include other foreign public officials. The category which embraced EU officials was a broad category comprising of community civil servants, national civil servants of other Member States of the European Union, members of the European Commission, members of the European Parliament, members of the European Court of Justice or the Court of Auditors of the European Community. Since the 2007 reform,

14 Cour de cassation, chambre criminelle (C.cass., ch. Crim.), 10 March 2004, no. 02-85285: "pour déclarer Alain P... coupable de trafic d'influence, les juges relèvent que le prévenu a offert ou vendu, divers objets à des prix très avantageux, à certains agents de la DCN, qu'il a invités à de nombreuses reprises au restaurant; que, dans le même temps, il a obtenu, par l'intermédiaire de ces agents, en avril 1995, de nombreux marchés de fourniture et de maintenance. Que les juges ajoutent qu'il est manifeste que le prévenu n'a procuré ces avantages aux agents précités qu'en considération de l'influence réelle ou supposée qu'il leur prêtait dans l'attribution des commandes ou marchés relevant de leur compétence...".

("In order for Alain P ... to be declared guilty of passive bribery, the judges point out that the defendant must have offered or sold various objects at very cheap conditions to certain agents of the "DCN", whom he has invited to restaurants on numerous occasions; that during the same time, he was awarded in April 1995, numerous business contracts in deliverance and maintenance from the intermediary of these agents. The judges also add that it is obvious that the defendant did transfer the benefits to these agents only with regard to the factual or assumed influence to facilitate the contracts or business transactions falling within their competence.") 
this rule has assumed the legal definition of Art. 432-11 CP, which addressed officials of a foreign state or an international public organisation (Art. 435-1 CP). Last but not the least, the fourth category involves persons "not holding any public office". Art. 445$1 \mathrm{CP}$ describes this category as relating to persons who do not hold any public authority, are not discharging a public service mission, do not hold any public electoral mandate, but who, within a professional or social context, have a leadership role or work for a natural or legal person or for any organisation. ${ }^{15}$ This stipulation replaces a former rule in the Labour Code (Code du travail, CT) relating to corruption by company leaders and employees. ${ }^{16}$

\section{Sanctions}

The sanctions provided for by the Criminal Code are typical criminal sanctions, for instance the loss of liberty for judges involved in passive corruption benefiting convicted persons (Art. 434-9(3) CP), fines of up to 200.000 EUR for natural persons (Art. 43211, 433-1, 434-9, 435-1 - 435-4 CP) and up to 750.000 EUR for legal persons (Art. 433-25 CP), as well as the confiscation of illegally obtained items (Art. 432-17, $3^{\circ} \mathrm{CP}$ ).

This relatively clear scheme contrasts with the sheer complexity of reality, as demonstrated by case law.

\section{Illustrative Case Law}

The Cour de cassation has handled a small number of corruption cases. One of these cases which occurred in the final hour of one of France's biggest corruption scandals of the last decade, illustrates the complexity of the reality of corruption.

Between 1988 and 1995, certain construction companies received sensitive commercial information, from public officials, that enabled them to secure public procurement contracts. These companies then received illicit payments, for non existent services or overvalued ones, in turn paying part of the monies received to the most important political parties in France, amongst them the parties of former President Chirac (RPR) and former President Mitterrand (socialist party). A rate was prescribed according to which each party was allocated these monies. Public officials, heads of construction companies and members of these political parties were found guilty of a range of offences, depending on their position and their involvement. The affected heads of the construction companies were held liable for breach of trust (Art. 314-1 CP), use of company property in bad faith (Art. L. 243-3, $4^{\circ}$ Com.C.), corruption and unfair competition law breaches. The public officials were held liable for favouritism within public procurement, whilst sentences were imposed on the money collectors and politicians, for corruption and traf-

15 “Une personne qui, sans être dépositaire de l'autorité publique, ni chargée d'une mission de service public, ni investie d'un mandat électif public exerce, dans le cadre d'une activité professionnelle ou sociale, a une fonction de direction ou un travail pour une personne physique ou morale ou pour un organisme quelconque."

16 Ex. Art. L. 152-6 CT. 
ficking in influence. ${ }^{17}$ This case demonstrates that in order to impose sanctions for the commission of corruption, even in a corruption case involving a single and complete scheme, judges have to draw on many different legal texts, taken from various sources, including the Criminal Code, Commercial Code and unfair competition laws.

Once sentenced, convicted corruptors have to compensate aggrieved persons for their losses. According to French law, this compensation derives from civil law practices.

\section{Civil Law Treatment}

\section{I. $\quad$ Prescription and Evidential Proof}

According to Art. $8 \mathrm{CCP}$, offences of corruption have a prescription period of three years, as they belong to the category of "délits stricts". According to case law, this offence is renewed by any new act of corruption, consequently the prescription period starts with the last instance of corruption. ${ }^{18}$ If the facts have been dissimulated, the prescription period starts once the facts come to light. ${ }^{19}$ The civil law action is dependent on this rule, as Art. $10 \mathrm{CCP}$ stipulates that a civil law action ("action civile") related to a criminal law action cannot be instigated following the prescription period of the criminal law action.

Civil law partly deals with evidential proof and has an impact on the proof of corruption. Proof of evidence is submitted to a general principle of loyalty (fairness), hence it must be obtained and produced in a fair manner. In the context of corruption, the interpretation of this rule has been enlarged.

In a case dealt with in January 2008 by the Criminal Chamber of the Cour de cassation, a public official from Mayotte had asked for a bribe from a person who had submitted a tender for the construction of a leisure park. The tenderer made an appointment with the public official, informed the police, withdrew money from his bank, recording the serial numbers appearing on each bill, and asked that the police turn up to witness the transaction. When the police arrived, they found the public official in possession of 5000 EUR which he had already received. Upon being charged with trafficking in influence, the defendant argued that the case should be discharged on the grounds of entrapment. The court refused his request. ${ }^{20}$

In order to comply with Art. 9 of the Civil Law Convention of the European Council and to ensure that whistleblowers were afforded protection, French labour law underwent reforms through the incorporation of Art. L. 1161-1 into the Labour Code. This detailed provision makes it unlawful for an employer to discriminate in any way against an employee or a job applicant, who reports in good faith the facts of corruption, made

17 C. cass., ch. crim., 20 February 2008, Affaire des marchés truqués de rénovation des lycées de l'Île de France (Scandal of the restoration of colleges of Île de France), no. 06-44964.

18 C. Cass., ch. crim., 6 February 1969, Bulletin criminel (Bull. Crim.), no. 67.

19 C. Cass., ch. crim., 19 March 2008 no. 07-82124, to be published in Bull. crim.

20 C. cass., ch. crim. 16 January 2008, no. 07-87633, Bull. crim, no. 14. 
known to him or her by virtue of their position and responsibilities, to either his or her employer or the relevant authorities, judicial or administrative. ${ }^{21}$ Nevertheless this provision is limited in its scope for two reasons.

The first reason relates to the omission of the phrases "reasonable grounds to suspect corruption" or "suspicion" from the French text, which effectively means that a whistleblower is not afforded protection as such until the corruption is established.

The second reason arises from the text itself and relates to the burden of proof, which is borne by the employee and the defendant. ${ }^{22}$

\section{Validity of Contracts}

Corruption in French law is only concerned with the bribery agreement itself, namely the agreement between the agent and the briber, whilst ignoring the agreement between the briber and principal. To start with, the bribery agreement itself is void pursuant to French contract law. According to contract law principles, a contract must comply with essential prerequisites: it must result from free will, have an "object" (objet) and be based on "cause". In the case of a bribery agreement, the object of the contract violates Art. 1128 Civil Code (code civil, CC), according to which "[o]nly things which constitute the subject matter of legal transactions between private individuals may be regarded as objects of agreements." Moreover, it violates the conditions of cause, as pursuant to

21 Art. L. 1161 CT: "Aucune personne ne peut être écartée d'une procédure de recrutement ou de l'accès à un stage ou à une période de formation en entreprise, aucun salarié ne peut être sanctionné, licencié ou faire l'objet d'une mesure discriminatoire, directe ou indirecte, notamment en matière de rémunération, de formation, de reclassement, d'affectation, de qualification, de classification, de promotion professionnelle, de mutation ou de renouvellement de contrat pour avoir relaté ou témoigné, de bonne foi, soit à son employeur, soit aux autorités judiciaires ou administratives, de faits de corruption dont il aurait eu connaissance dans l'exercice de ses fonctions.

Toute rupture du contrat de travail qui en résulterait, toute disposition ou tout acte contraire est nul de plein droit."

("No person should be denied recruitment opportunities or access to an internship or period of training within an entity. No employee may be subject to disciplinary procedures, dismissed or be treated in a discriminatory manner, directly or indirectly, especially with regards to remuneration, training, rehabilitation, official deployment, qualification, classification, professional advancement, transfer of employees or renewal of the contract for having revealed or disclosed, in good faith, either to his employer or to the judicial or administrative authorities facts of corruption which he has observed during the exercise of his functions.

Any breach of contract which results there from, any disposition or contrary act is null and void.").

22 Art. L. 1161 al. 3 CT: le salarié "établit des faits qui permettent de présumer qu'il a relaté ou témoigné de faits de corruption, il incombe à la partie défenderesse, au vu de ces éléments, de prouver que sa décision est justifiée par des éléments objectifs étrangers aux déclarations ou au témoignage du salarié. Le juge forme sa conviction après avoir ordonné, en cas de besoin, toutes les mesures d'instruction qu'il estime utiles."

("After having investigated and discovered facts which lead to the assumption that the employee has been engaged in incidents of corruption, the burden of proof is on the defendant party to show that his/her actions were justified by objective elements other than declarations or the testimony of the employee regarding these elements. The judge's decision is based on results of investigations after having ordered, in the case of necessity, all the measures of investigation which he considers convenient."). 
Art. $1133 \mathrm{CC}$, "[a] cause is unlawful where it is prohibited by legislation, where it is contrary to public morals or to public policy." In this respect, corruption is contrary to public morals as well as public policy. As a matter of fact, the validity of such contracts has never constituted the topic of direct debates in case law, ${ }^{23}$ but it is an implicit assumption in damages suits as the legal basis for the claim is not contractual remedies but tort law.

As a result of this narrow interpretation, the validity of the contract between briber and principal resulting from the corruptive act has never been challenged. Where the contract is an administrative contract, for instance where it is aimed at a public service delegation, its licence can be repealed when resulting from corruption, according to administrative law. ${ }^{24}$ Where the contract is a civil contract, for instance, where it is the result of a public procurement, it remains valid. If it were possible to challenge the validity of a contract, French law would offer legal bases for this. The bribery agreement could be considered the "cause" of the contract resulting in it being found immoral according to Art. $1133 \mathrm{CC}$. The contract would be void $a b$ initio. Case law does not provide examples of this. Another legal basis could be fraud and the contract could be considered to be the result of a fraudulent act. According to French law, the sanction for fraud is the "inopposability" of its results, which means that certain aspects of the affected contract remain valid whilst its main effects are inhibited.

\section{Remedies and Damages}

A claim for damages occurs within the criminal action, as the Code of Criminal Procedure allows for claims for civil damages (Art. 2 CPP). ${ }^{25}$ Such claims can only succeed where the plaintiff is able to prove "personal and direct" damage resulting from the offence. Consequently secondary victims are excluded from the scope of this rule.

A civil law action, although within the criminal suit, has to comply with civil law rules. Damages are common civil law remedies and occur when someone is liable based on the facts. Restitution is usually a criminal remedy in relation to criminal liability. Within civil law, it is the consequence of the nullity of the contract, as consequences of nullity include the reestablishment of the previous situation of the parties. But as we have seen, the validity of contracts has never been challenged. Hence, restitutions and restitution of the bribe have never been sought - with the consequence that damages are the only civil law remedy. However, corruption is a very special situation, which does not entirely fit in with civil law principles. This has in turn resulted in some debate. Up till now, the situation has not been really resolved.

23 Besides C. cass., ch. crim., 13 June 1978, no. 77-91762, where a claim has been raised initially by the agent in order to receive the "commission", but the claimant changed the legal way and claimed for damages.

24 For instance in the case of the corruption of the town of Cannes, C. cass., ch. Crim 14 March 2007, no. 06-81010.

25 Art. 2 CPP: "Civil action, which is aimed at the reparation of the damage suffered because of a felony, a misdemeanour or a petty offence is open to all those who have personally suffered damage directly caused by the offence." 


\section{Persons Eligible to Sue for Damages}

The first issue debated on is whether or not a person involved in corruption could be eligible to sue for damages.

In a case, handled in 1978, the question arose but was not directly responded to. In this case, both parties had been involved in active and passive trafficking in influence, before a conflict arose between them. The agent first sued for payment of the agreed commissions and then claimed for compensation in relation to his loss. The Court did not reject the claim on the basis of immorality, but insisted that the civil compensation required a personal loss. ${ }^{26}$

In a case reported in 1992, the criminal court relied on this earlier decision and in turn directly responded to this question. In this case, the criminal court ruled that even though the offence of passive corruption had been enacted mainly in order to protect the general interest, it also served to protect private persons, who may have suffered a loss as a result of having been induced to offer gifts and presents. Nevertheless, the judges in this case also allowed for an exception to this rule in the event that the claimant provoked the offence himself. ${ }^{27}$ The Court implied in its ruling that a person involved in corruption even one who had committed some reprehensible acts, could sue for damages. This needed to be clarified in order to establish who had locus standi.

In 2001, the judges touched on this point in a case involving slush payments made in exchange for the allocation of social housing and the authorisation of the sale of newspapers from a kiosk. The appellate court in this case held that the money should be refunded to these persons as compensation for their loss. The decision was subsequently repealed, on the grounds that a person who had made a payment in bad faith to the principal within a trafficking in influence, in order to obtain a favourable decision from a public authority could not be eligible in a civil claim for compensation in relation to their loss. ${ }^{28}$

As a result of this judge-made law, the answer to the question regarding who is eligible to claim compensation for a loss is still unclear. It can be assumed that any person who has suffered a loss without committing any offence is eligible. However, such a situation is quite exceptional where corruption is involved, as anyone involved has either given or received some money or advantage and has consequently committed an offence. Perhaps the court could consider the gravity of the offence and whether or not it resulted from undue influence. An interpretation a contrario of these cases leads to the conclusion that a payment made in good faith would not be an impediment to a claim. The question is, what is a payment in good faith. The answer depends on policy considerations as implemented by judges. In order to combat corruption efficiently, the court should provide incentives for whistleblowers, who in most cases do not have clean hands.

\section{Vicarious Liability}

The second debate relates to vicarious liability. Whereas, according to French tort law, liability for personal misconduct is the usual legal treatment for corruption (Art. 1382

26 C. Cass., ch. crim., 13 June 1978, no. 77-91762.

27 C. cass., ch. crim., 1 December 1992, Droit pénal. 1993, no. 126, obs. Véron.

28 C. cass., ch. crim., 7 February 2001, Bull. crim. no. 38. 
$\mathrm{CC})$, the question also arose as to whether vicarious liability, such as employer's liability, could apply (Art. 1384 al. 5 CC). This was rejected in 2003 in a case where a bribed banker had made payments through two promissory notes when the bank should have frozen the assets of the bankrupt. The trustee in bankruptcy sued the bank for damages, on the basis of employer's liability. The Cour d'appel held that as the agent who had received a bribe, was aware of the illegality of his act, this act had been performed outside the course of his employment, without any authorisation and without him carrying out any of his legal duties as an employee of the bank. This decision was subsequently approved by the Cour de cassation as conforming with case law on employer's liability. ${ }^{29}$

\section{Injuries that Qualify as Damage}

The third debate relates to the nature of injuries that qualify as damage resulting from corruption. In a case handled by the Cour de cassation in March 2007, whereas material damage was disallowed by the Court, the Court made an award in relation to moral damage. In this case, the town of Cannes sued for damages after their mayor had been convicted of corruption. The facts of this case are as follows: the mayor had allocated a gambling licence to a company without complying with legal requirements, after receiving a bribe. Consequently, the Minister of Interior revoked the authorisation and refused to allocate it to any company until the legal proceedings, involving the public service delegation, had concluded. As a result, the town of Cannes could not benefit from taxes, such as the tax levied to pay an annual contribution supporting artistic effort and those taxes imposed on gambling, for the period of two years. In this case, the town acting in the capacity of a legal person, sued the bribers. The judges held that this damage was not direct damage, consequent to the corruption, but was instead the consequence of the Minister's decision to revoke and refuse a licence before the legal proceedings were finalised. Therefore this could not be considered a loss directly resulting from the infringement. ${ }^{30}$ This statement was subsequently approved by the Cour de cassation, which also reserved the possibility of compensation for the "loss of chance" in an obiter dictum.

On the other hand, the judges did recognise that loss of reputation qualifies as damage. This is interesting in so far as the party suffering the said loss of reputation is in fact a legal person (in this case, the town of Cannes). The town alleged that they had suffered a loss of reputation worldwide, in the context of their role as host of the prestigious film festival. The mayor of the town was the main person involved but corruption resulted from the behaviour of the defendant who had paid the bribe. In this case, damages were quantified at 100.000 EUR. ${ }^{31}$

\section{Liability of Several Persons}

The claimants in the latter case also disputed the liability for damages. The final decision on this point is most interesting as it is a departure from general civil law principles. According to the rules of personal responsibility, where several persons share responsibility for a loss, the responsibility assumed by each party would depend on the

29 C. cass., 2nd chambre civile, 23 May 2003, no. 12-12198.

30 C. cass., ch. crim., 14 March 2007, no. 06-81010.

31 C. cass., ch. crim., 14 March 2007, no. 06-81010. 
gravity of their wrongdoing, which judges have to evaluate. In this corruption case, the judges decided to impose liability on each and every party without considering the respective gravity of their wrongdoing, accordingly liability was shared equally between the parties. Two appellants then attempted to argue that they were less liable than the mayor, as it was the mayor (who had been convicted twice) who had compelled them to commit the corrupt act in the first place. This argument was rejected on the grounds that corruption and complicity in corruption are related (connexes).

\section{Conclusion}

Is this multifaceted framework of rules dealing with corruption, a success or a failure? According to the official statistics report on Justice, case law relating to corruption of public officials has increased. Whilst in 2001 there were 211 cases involving corruption of public officials, in 2005, there were 280 cases. ${ }^{32}$

In contrast, corruption within the private sector remains difficult to evaluate as it falls under various types of infringement, not always directly related to corruption but rather to a moral breach of duty by a member of the corporation.

French law also offers a wide range of rules to combat corruption; judges and lawyers agree that corruption cases are quite rare. This totally contradicts the level of adverse publicity generated by these cases in the media. For instance, a recently reported corruption scandal in France reveals how widespread and unregulated corruption still is. In this case a special division of the Finance Ministry ${ }^{33}$ discovered in September 2007 that numerous cash payments had been made by the Vice-President of the MEDEF (Mouvement des entreprises françaises, French union of employers) who was also the head of the Union of the Steel Industry. ${ }^{34}$ When this division turned the case over to the financial public prosecutor, the latter estimated the payments to be around 19 million Euros. ${ }^{35}$ In his defence, the VP of MEDEF attempted to argue that the payments had been used for the purpose of facilitating social and trade relations. ${ }^{36}$

A special fund of the Union of the Steel Industry with a deposit of 600 million EUR was also discovered, which had apparently existed since 1972 for the purpose of "preventing emergency cases", according to a Union Representative. ${ }^{37}$ Because of this scandal, the VP of MEDEF was compelled to resign from his post, though he received a golden hand-shake of 1.5 million EUR and an allocation of 20.000 EUR a month from the Union. The Steel Union also declared that it would compensate for any financial

32 Annual statistic of justice 2007, 195, available at $<$ http://www.justice.gouv.fr>.

33 Traitement du renseignement et action contre les circuits financiers clandestins (TRACFIN), cellule française de la lutte anti-blanchiment.

34 Le monde, 26 September 2007.

35 Challenges, 2 September 2008, Affaire UIMM <http://www.challenges.fr/actualites/business/2007 1016.CHA1981/chronologie_sur_laffaire_gautiersauvagnac.html>.

36 Libération, 15 October 2007.

37 Le Monde, 24 October 2007. 
sanctions brought against him and no plans were made to demand prosecution of this case against the Union Representative. ${ }^{38}$

A comparison of this case with the legal framework against corruption clearly shows that there are discrepancies between law and reality. Firstly, the huge sums of money involved dwarf the fines found in the Penal Code. Secondly, corruption is addressed in law as a personal wrongdoing and breach of morality, but this is not always the case, as the situation above illustrates. This case seems to illustrate that the apparent "victim", namely the Union of the Steel Industry, also had a vested interest.

38 Le Monde, 1 March 2008. 